\title{
Effects of Varying Nitrogen Fertilization on Growth, Yield and Flowering of Capsicum annuum (California wonder)
}

\author{
Usisipho Kamnqa, Ninon G.E.R. Etsassala, Enoch A. Akinpelu and Felix Nchu*
}

\begin{abstract}
An experiment was conducted to investigate the effects of nitrogen $(\mathrm{N})$ concentration on growth and yield of sweet chili (Capsicum annuum), cultivar California wonder, over four weeks with to determine the best $\mathrm{N}$ concentration for growing this chili cultivar hydroponically. We assessed plant growth and aphid (Myzus persicae [Homoptera]) infestation levels after treating plants with different nitrogen concentrations: $65 \mathrm{ppm} \mathrm{N}, 130 \mathrm{ppm} \mathrm{N}, 260 \mathrm{ppm} \mathrm{N}$, and $520 \mathrm{ppm} \mathrm{N}$. The results indicated that varying $\mathrm{N}$ fertilization had varied effects on plant growth depending on the parameter that was assessed. The plants that were exposed to higher $\mathrm{N}$ treatments were significantly shorter compared to the lower treatments. At the range of $\mathrm{N}$ concentrations tested, no significant effect was observed on leaf number, root fresh weight, and dry weight of the plant's aerial part. Generally, the number of flowers produced by $C$. annuиm reduced significantly with increased $\mathrm{N}$ treatment. Leaf green color intensity (greenness) varied from pale green in $65 \mathrm{ppm} \mathrm{N}$ to dark green in 260 ppm $\mathrm{N}$ treatments. Symptoms of nitrogen toxicity - leaf burning (brown and yellow patches on the leaves) were observed among plants exposed to the highest $\mathrm{N}(520 \mathrm{ppm} \mathrm{N})$ treatment. Interestingly, insect infestation levels varied according to the leaf greenness. Fewer and no insects were found on plants exposed to the highest $\mathrm{N}$ treatment (which had brown and yellow leaf patches) and the lowest $\mathrm{N}$ treatment (pale green leaves), respectively, compared to the treatment (260 ppm $\mathrm{N})$ that had plants with dark green leaves and the highest aphid infestation level. In conclusion, this study suggests that $65 \mathrm{ppm} \mathrm{N}$ is the best concentration for cultivating the chili cultivar California Wonder hydroponically.
\end{abstract}

Keywords-Ammonium nitrate, Capsicum annuum, nitrogen

\section{INTRODUCTION}

Chilli pepper (Capsicum annuum) is a widely cultivated vegetable species that has been used since time immemorial for human health benefits and food flavouring [1]. Depending on the location, Capsicum annuum can grow as a shrub, an annual or a perennial herb. Chilli pepper is a good source of vitamins A, C, E, B1 and B2, potassium, phosphorus, and calcium. Moreover, it is one of the most valuable medicinal plants in pharmaceutical industries because of its high amount of antioxidants [2]. Numerous secondary metabolites such as capsaicin, capsicum, carotene, thiamine and ascorbic acid are

Manuscript received August 10, 2020. This work was supported by Cape Peninsula University of Technology, University Research Fund Grant no: R166.

Usisipho Kamnqa, N.G.E.R. Etsassala, E. A. Akinpelu, and F. Nchu are in the Department of Horticultural Sciences, Cape Peninsula University of Technology, Bellville Campus, Symphony Way, PO Box 1906, Bellville, 7535, South Africa. the main active constituents of Capsicum annuum [3]. Because of its high value and demand, researchers are continuously finding ways to improve the yield and quality of $C$. annuum; and hydroponics presents an interesting opportunity to efficiently control and manipulate environmental factors, including nutrients for improving crop production [4].

Nitrogen is a major plant nutrient, and it is needed in metabolic processes, vegetative growth, and plant productivity [5]. Nitrogen fertilizers enhance chlorophyll synthesis in plants, which causes an increase in carbohydrate synthesis [6]. Nitrogen supply improves the growth performance of the plant, including pepper [7,8]. On the other hand, inadequate nitrogen could result in stunted growth, the spindly appearance of plants, reduced growth of leaves, chlorosis, premature senescence of older leaves, and restricted root growth and branching, among others [9]. While nitrogen fertilization favors plant growth and health, excessive supply of nitrogen can also be detrimental and even toxic to plants [10]. High nitrogen availability can induce physiological susceptibility to pest attacks [11, 12]. For example, supplying nitrogen at higher rates increased Bemisia tabaci nymphs' infestations, Empoasca decipiens and Thrips tabaci on tomato crop, Lycopersicon esculentum L. [13].

Because in hydroponic cultivation, nutrient elements are delivered straight to the roots of plants [14], the risk of excessive supply of nutrients to plant is high. Furthermore, since each plant cultivar and species have specific nutrient requirements, it is necessary to determine the optimum nutrient concentration of each nutrient element in hydroponics. Hence, this study was carried out to assess the effects of nitrogen on the growth, flowering, and aphid infestations levels of $C$. annuиm.

\section{MATERIALS AND METHODS}

\section{A. Plant materials}

Capsicum annuum (California wonder) seedlings were obtained from a local retail nursery Starke Ayres nursery at Rosebank, Western Cape, South Africa. The seedlings were imbedded in 20 plastic pots containing a substrate mix of 2 parts river sand, 2 parts coco coir and 1 part vermiculite. The pots were placed in a temperature-controlled with the following growing conditions: Temperatures (day; $17-22{ }^{\circ} \mathrm{C}$ and evening; $15-18{ }^{\circ} \mathrm{C}$ ). A total of 20 seedlings were allocated to four treatments, each with 5 replicates, the substrate was sterilised by treating with Captab ${ }^{\circledR}(4 \mathrm{~g} / \mathrm{L})$ (Universal Crop Protection (PTY) LTD, Kempton Park, South Africa), and rinsing with sterile distilled water, before use. 


\section{B. Nutrient solutions}

A stock solution of ammonium nitrate was prepared using $20 \mathrm{~g}$ of $\mathrm{NH}_{4} \mathrm{NO}_{3}$ (Sigma-Aldrich, Johannesburg) in $250 \mathrm{~mL}$ of water. The hydroponic nutrient solution was prepared using Nutrifeed ${ }^{\circledR} 5 \mathrm{~g} / 5 \mathrm{~L}$ of water. The ammonium nitrate stock solution was used to adjust the final nitrogen concentrations to 65 ppm, 130 ppm N, 260 ppm N, and 520 ppm N, representing four treatments, T1, T2, T3, and T4, respectively.

\section{Experimental design}

The experiment was conducted in a tunnel within the nursery of the Department of Horticultural Sciences, Cape Peninsula University of Technology, Bellville campus, Cape Town, South Africa. To test the effect of increased nitrogen on plant growth of $C$. annuum (cultivar, California wonder). The experimental design was a complete randomized block design consisting of four treatments, with each having five randomly-allocated plants (replicates). A total of 20 plants $(n=20)$ potted in $12 \mathrm{~cm}$ wide pots separately, were used in this study. Each pot was filled with river sand (2 parts), coco coir (2 parts), and vermiculite (1 part). The tunnel had residual green peach aphid (Myzus persicae [Homoptera]) infestations, and the influence of $\mathrm{N}$ treatment on aphid infestations was also assessed. All plants were hand irrigated daily for five days, with a $100 \mathrm{~mL}$ solution containing a mixture of Nutrifeed $\AA$ at $5 \mathrm{~g} / 5 \mathrm{~L}$ and ammonium nitrate at final nitrogen concentrations of $65 \mathrm{ppm}, 130 \mathrm{ppm} \mathrm{N}$, $260 \mathrm{ppm} \mathrm{N}$ and $520 \mathrm{ppm} \mathrm{N}$ representing treatments T1, T2, T3 and $\mathrm{T} 4$ respectively. Plants in $\mathrm{T}_{1}$ received a solution of Nutrifeed containing $65 \mathrm{ppm} \mathrm{N}$, while the higher treatments were supplemented with appropriate amounts of ammonium nitrate solution. In order to determine whether the nitrogen quantity received by plants influenced the growth of $C$. annuum, the height ( $\mathrm{cm} \mathrm{plant}^{-1}$ ); the number of leaves of each plant was measured once on Fridays over a period of four weeks post-treatment. The total numbers of flowers were counted; the length and width of the largest leaf in each plant were measured. At the end of the experiment, harvested plants were weighed to obtain fresh weight $\left(\mathrm{g} \mathrm{plant}^{-1}\right)$. The aphids (M. persicae) on plants were enumerated, and leaf color was compared among $\mathrm{N}$ treatments by visual observation. .

\section{Statistical analysis}

Collected data were analysed using one-way analysis of variance (ANOVA). Means were further separated using Tukey test. The level of statistical significance was $\mathrm{P}<0.05$. The analyses were performed using PAST.

\section{RESULTS AND DISCUSSION}

\section{A. Number of leaves}

Generally, plants in the highest treatment produced more leaves. The varying $\mathrm{N}$ treatment had a significant effect $(\mathrm{df}=3$. $16 ; \mathrm{p}<0.05)$ on the number of leaves at weeks 2 and 3 post treatment (Table I).

TABLE I: THE NUMBER OF LEAVES (MEAN \pm SE PLANT $^{-1}$ ) FOLLOWING EXPOSURE OF PLANTS TO OF FOUR N TREATMENTS

(T1 [65 PPM N], T2 [130 PPM N], T3 [260 PPMN] AND T4 [520 PPMN]) AT ONE TO FOUR WEEKS POST TREATMENT

\begin{tabular}{ccc}
\hline Weeks post-treatment & Treatments & $\begin{array}{c}\text { Numbers of leaves (Mean } \\
\pm \text { SE plant }\end{array}$ \\
\hline 1 & T1 & $12 \pm 0.55 \mathrm{a}$ \\
& T2 & $12 \pm 0.55 \mathrm{a}$ \\
& T3 & $12.8 \pm 0.37 \mathrm{a}$ \\
& T4 & $11.8 \pm 0.58 \mathrm{a}$ \\
& T1 & $14.8 \pm 1.0 \mathrm{~b}$ \\
& T2 & $16.6 \pm 0.8 \mathrm{ab}$ \\
& T3 & $19.4 \pm 1.3 \mathrm{a}$ \\
& T4 & $21.2 \pm 1.2 \mathrm{a}$ \\
& T1 & $30.8 \pm 1.0 \mathrm{~b}$ \\
& T2 & $30.8 \pm 1.3 \mathrm{~b}$ \\
& T3 & $36.6 \pm 2.2 \mathrm{a}$ \\
& T4 & $35.8 \pm 1.4 \mathrm{a}$ \\
& T1 & $35.8 \pm 0.7 \mathrm{a}$ \\
& T2 & $34.8 \pm 1.5 \mathrm{a}$ \\
& T3 & $38.8 \pm 2.4 \mathrm{a}$ \\
& T4 & $41.2 \pm 1.4 \mathrm{a}$ \\
\hline
\end{tabular}

Means followed by the same lowercase letters in each column are not significantly different ( $\mathrm{p}>0.05$ following Tukey test) at weeks 1, 2, 3 or 4 .

\section{B. Height of plant}

The differences in plant height were not significant at one, two and three weeks post treatment following exposure to the different $\mathrm{N}$ treatments (Table II). However, at week 4, plants in the $520 \mathrm{ppm}$ treatment had the shortest height of plants $(28.3 \pm$ $0.3 \mathrm{~cm})$, which was statistically significant $(\mathrm{df}=3.16 ; \mathrm{f}=6 ; \mathrm{p}<$ $0.01)$ when compared with the other three treatments.

TABLE II: THE PLANT HEIGHT (MEAN \pm SE CM PLANT ${ }^{-1}$ ) FOLLOWING EXPOSURE OF PLANTS TO FOUR N TREATMENTS AT WEEKS ONE TO FOUR POST TREATMENT

\begin{tabular}{ccc}
\hline Numbers of weeks & Treatments & $\begin{array}{c}\text { Numbers of leaves (Mean } \pm \text { SE } \\
\text { plant }^{-1}\end{array}$ \\
\hline 1 & T1 & $16.1 \pm 1.1 \mathrm{a}$ \\
& T2 & $13.9 \pm 0.8 \mathrm{a}$ \\
T3 & $14.4 \pm 1.1 \mathrm{a}$ \\
& T4 & $15.7 \pm 0.5 \mathrm{a}$ \\
\hline \multirow{2}{*}{2} & T1 & $18.7 \pm 0.8 \mathrm{a}$ \\
& T2 & $16.6 \pm 0.8 \mathrm{a}$ \\
& T3 & $18.5 \pm 1.1 \mathrm{a}$ \\
& T4 & $19.2 \pm 0.5 \mathrm{a}$ \\
& T1 & $28.7 \pm 0.5 \mathrm{a}$ \\
& T2 & $28.5 \pm 1.0 \mathrm{a}$ \\
& T3 & $29.4 \pm 2.1 \mathrm{a}$ \\
& T4 & $25.8 \pm 0.7 \mathrm{a}$ \\
& T1 & $34.5 \pm 0.9 \mathrm{a}$ \\
& T2 & $33.5 \pm 0.9 \mathrm{a}$ \\
& T3 & $31.6 \pm 1.6 \mathrm{ab}$ \\
& T4 & $28.3 \pm 0.3 \mathrm{~b}$ \\
\hline
\end{tabular}

Means followed by the same lowercase letters in each column are not significantly different ( $\mathrm{p}>0.05$ following Tukey test) at weeks 1, 2, 3 or 4

\section{Leaf length and width}

Varying $\mathrm{N}$ concentrations had significant effects $(\mathrm{df}=3,16 ; \mathrm{p}$ $<0.01$ ) on the leaf lengths (ranging from $13.0 \pm 0.3$ to $14 \pm 0.7$ $\mathrm{cm})$ and leaf width $(6.5 \pm 0.2-8.8 \pm 0.6 \mathrm{~cm})$ of the largest leaves (Table III). Specifically, T2 and T3 plants had the longest and widest leaves.

TABLE III: LEAF WidTH AND LENGTH (MEAN \pm SE CM PLANT ${ }^{-1}$ ) Following EXPosure OF Plants To Four N TREaTMENTS At Four WEEKS Post TREATMENT

\begin{tabular}{lll}
\hline Treatments & $\begin{array}{l}\text { Leaf width (Mean } \pm \text { SE } \\
\text { cm plant }^{-1}\end{array}$ & $\begin{array}{l}\text { Leaf length (Mean } \pm \\
\left.\text { SE cm plant }^{-1}\right)\end{array}$ \\
\hline T1 $(65 \mathrm{ppm} \mathrm{N})$ & $6.5 \pm 0.2 \mathrm{~b}$ & $13.0 \pm 0.3 \mathrm{~b}$ \\
T2 $(130 \mathrm{ppm} \mathrm{N})$ & $8.3 \pm 0.3 \mathrm{a}$ & $16.1 \pm 0.4 \mathrm{a}$
\end{tabular}


$\mathrm{T} 3(260 \mathrm{ppm} \mathrm{N}) \quad 8.8 \pm 0.6 \mathrm{a} \quad 18 \pm 0.5 \mathrm{a}$

$\mathrm{T} 4(520 \mathrm{ppm} \mathrm{N}) \quad 7.7 \pm 0.2 \mathrm{ab} \quad 14 \pm 0.7 \mathrm{~b}$

Means followed by the same lowercase letters in each column are not

significantly different at $\mathrm{p}>0.05$ following Tukey test.

\section{Fresh and dry weights of plant root and aerial parts}

While root fresh weight reduced with increasing concentration of $\mathrm{N}$, the effect of $\mathrm{N}$ treatment on root weight was not statistically significant $(\mathrm{df}=3.24 ; \mathrm{f}=2.1 ; \mathrm{p}>0.05)$ on fresh root weight, with the plants in the lowest $\mathrm{N}$ treatment having the heaviest roots plants, while plants exposed to the highest concentration of $\mathrm{N}$ had the lowest root weight (Table IV). The fresh weight of the aerial parts varied significantly $(\mathrm{df}=3.16 ; \mathrm{f}$ $=6.4 ; \mathrm{p}<0.05)$ among plants in the different treatments. The dry weight of plant roots varied significantly among the four $\mathrm{N}$ treatments $($ Table $\mathrm{V})$. Roots from the lowest $\mathrm{N}$ treatment weighed the least $\left(2.9 \pm 0.1 \mathrm{~g} \mathrm{plant}^{-1}\right)($ Table V). Whereas, the dry weights of the aerial part of the plants did not vary significantly $(\mathrm{df}=3.24 ; 2.17 ; \mathrm{p}>0.05)$.

TABLE IV: FRESH WEIGHTS OF PLANT ROOTS AND AERIAL PARTS $\left(\right.$ MEAN \pm SE G PLANT $\left.{ }^{-1}\right)$ FOLLOWING EXPOSURE OF PLANTS TO FOUR N TREATMENTS AT HARVEST (FOUR WEEKS POST TREATMENT)

\begin{tabular}{|c|c|c|}
\hline Treatments & $\begin{array}{l}\text { Fresh weight of roots } \\
\left(\text { Mean } \pm \text { SE g plant }{ }^{-1}\right)\end{array}$ & $\begin{array}{l}\text { Fresh weight of aerial } \\
\text { parts (Mean } \pm \text { SE } g \\
\text { plant }^{-1} \text { ) }\end{array}$ \\
\hline T1 $(65 \mathrm{ppm} \mathrm{N})$ & $11.4 \pm 1.6 \mathrm{a}$ & $39.5 \pm 2.6 \mathrm{a}$ \\
\hline $\mathrm{T} 2(130 \mathrm{ppm} \mathrm{N})$ & $10.6 \pm 1.1 \mathrm{a}$ & $38.7 \pm 4.0 \mathrm{a}$ \\
\hline T3 $(260 \mathrm{ppm} \mathrm{N})$ & $9.0 \pm 1.9 \mathrm{a}$ & $25.5 \pm 3.0 \mathrm{~b}$ \\
\hline $\mathrm{T} 4(520 \mathrm{ppm} \mathrm{N})$ & $6.8 \pm 0.7 \mathrm{a}$ & $43.2 \pm 2.4 \mathrm{a}$ \\
\hline
\end{tabular}

Means followed by the same lowercase letters in each column are not significantly different at $p>0.05$ following Tukey test.

TABLE V: DRY WEIGHTS OF PLANT ROOTS AND AERIAL PARTS $\left(\mathrm{MEAN} \pm \mathrm{SE} \mathrm{G} \mathrm{PLANT}^{-1}\right)$ FOLLOWING EXPOSURE OF PLANTS TO FOUR N TREATMENTS AT FOUR WEEKS POST TREATMENT

\begin{tabular}{lll}
\hline Treatments & $\begin{array}{l}\text { Dry weight of root part } \\
(\text { Mean } \pm \text { SE g plant }\end{array}$ & $\begin{array}{l}\text { Dry weight of aerial } \\
\text { part (Mean } \pm \text { SE g } \\
\left.\text { plant }^{-1}\right)\end{array}$ \\
\hline T1 $(65 \mathrm{ppm} \mathrm{N})$ & $2.9 \pm 0.1 \mathrm{~b}$ & $6.3 \pm 0.8 \mathrm{a}$ \\
T2 $(130 \mathrm{ppm} \mathrm{N})$ & $4.1 \pm 0.1 \mathrm{a}$ & $6.2 \pm 0.6 \mathrm{a}$ \\
T3 $(260 \mathrm{ppm} \mathrm{N})$ & $4.5 \pm 0.3 \mathrm{a}$ & $4.5 \pm 0.4 \mathrm{a}$ \\
$\mathrm{T} 4(520 \mathrm{ppm} \mathrm{N})$ & $4.5 \pm 0.3 \mathrm{a}$ & $4.6 \pm 0.6 \mathrm{a}$ \\
\hline
\end{tabular}

Means followed by the same lowercase letters in each column are not

significantly different ( $p>0.05$ following Tukey test) at weeks $1,2,3$ or 4

\section{E. Number of flowers}

Nitrogen treatment had a significant effect $(\mathrm{df}=3.16$; $\mathrm{p}<$ 0.01 ) on plant flowering with plants in the lowest $\mathrm{N}$ treatment producing the highest number of flowers $\left(18 \pm 0.4\right.$ plant $\left.^{-1}\right)$ (Table VI).

TABLE VI: THE NUMBER OF FLOWERS (MEAN \pm SE PLANT $^{-1}$ ) FOLLOWING EXPOSURE OF PLANTS TO FOUR N TREATMENTS AT FOUR WEEKS POST-TREATMENT

\begin{tabular}{|c|c|}
\hline Treatment & $\begin{array}{l}\text { Number of flower (Mean } \pm \text { SE plant } \\
\text {-1 }\end{array}$ \\
\hline T1 (65 ppm N) & $18.0 \pm 0.5 \mathrm{a}$ \\
\hline $\mathrm{T} 2(130 \mathrm{ppm} \mathrm{N})$ & $14.8 \pm 1.3 \mathrm{~b}$ \\
\hline T3 $(260 \mathrm{ppm} \mathrm{N})$ & $11.2 \pm 0.6 b$ \\
\hline $\mathrm{T} 4(520 \mathrm{ppm} \mathrm{N})$ & $11.8 \pm 1.2 \mathrm{~b}$ \\
\hline
\end{tabular}

Means followed by the same lowercase letters in each column are not significantly different at $\mathrm{p}>0.05$ following Tukey test.

\section{F. Leaf colour}

Leaf colour intensity varied from pale green in $65 \mathrm{ppm} \mathrm{N}$ to dark green in $260 \mathrm{ppm} N$ treatments. Symptoms of nitrogen toxicity (browning and yellow patches on the leaves) were observed among plants exposed to the highest $(520 \mathrm{ppm} \mathrm{N})$ treatment (Fig. 1).

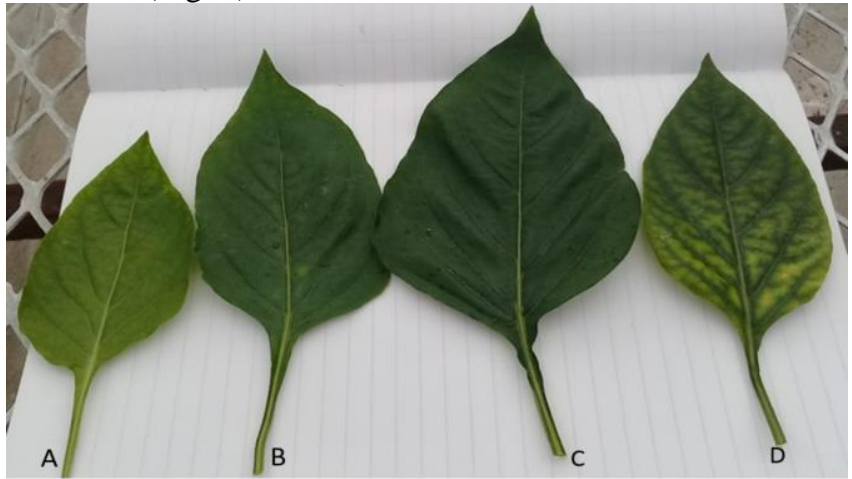

Fig. 1 The different plant leaf colours at harvest, $A=$ plant leaf from $\mathrm{T} 1$ $(65 \mathrm{ppm}), \mathrm{B}=$ plant leaf from T2 $(130 \mathrm{ppm}), \mathrm{C}=$ plant leaf from $\mathrm{T} 3$ $(260 \mathrm{ppm}), \mathrm{D}=$ plant leaf from T4 $(520 \mathrm{ppm})$.

\section{G. Aphid infestation on plant}

Aphid infestations were significantly $(\mathrm{df}=3.16 ; \mathrm{f}=19.76 ; \mathrm{p}<$ 0.01 ) influenced by nitrogen treatment (Table VII). No aphid infestation was observed on plants in the lowest treatment with the lowest $\mathrm{N}$ concentration (T1), while treatment $\mathrm{T} 3$ had the highest aphid infestations $\left(185.8 \pm 37.23\right.$ plant $\left.^{-1}\right)$ (Table VII). On closer observation, the insect infestation levels varied according to the leaf greenness; fewer and no insects were found on plants exposed to the highest $\mathrm{N}$ treatment (which had yellow leaf patches) and the lowest $\mathrm{N}$ treatment (pale green leaves), respectively, compared to the treatment $(260 \mathrm{ppm} \mathrm{N})$ that had plants with dark green leaves.

TABLE VII: APHID INFESTATION NUMBERS (MEAN \pm SE PLANT $^{-1}$ ) FOLLOWING EXPOSURE OF PLANTS TO FOUR N TREATMENTS AT FOUR WEEKS POST TREATMENT

\begin{tabular}{ll}
\hline Treatment & Number of aphid $\left(\right.$ Mean \pm SE plant $\left.^{-1}\right)$ \\
\hline T1 $(65 \mathrm{ppm} \mathrm{N})$ & $0.0 \mathrm{~b}$ \\
T2 $(130 \mathrm{ppm} \mathrm{N})$ & $34 \pm 10.1 \mathrm{~b}$ \\
T3 $(260 \mathrm{ppm} \mathrm{N})$ & $185.8 \pm 37.2 \mathrm{a}$ \\
T4 $(520 \mathrm{ppm} \mathrm{N})$ & $13.6 \pm 3.6 \mathrm{~b}$ \\
\hline
\end{tabular}

Means followed by the same lowercase letters in each column are not significantly different at $\mathrm{p}>0.05$ following Tukey test.

\section{DISCUSSION}

The effects of varying $\mathrm{N}$ treatment on the different growth parameters were mixed. Leaf number, fresh weight of roots were not affected by $\mathrm{N}$ treatment, while fresh plant height, leaf 
width and length, fresh weight of aerial parts, and dry weights of roots were influenced by varying $\mathrm{N}$ concentration. Based on the results, it is possible that the starting concentration of $65 \mathrm{ppm} \mathrm{N}$ is within the optimum $\mathrm{N}$ range for this cultivar of chili. While, generally, $\mathrm{N}$ fertilization favors biomass and growth of plants, plants' response to $\mathrm{N}$ addition varies among species and environmental conditions $[15,16]$. This reasoning is guided by the fact that at $65 \mathrm{ppm} \mathrm{N}$, the plants were generally healthy, and interestingly, plants in $65 \mathrm{ppm} \mathrm{N}$ treatment had a higher root fresh weight.

$\mathrm{N}$ treatment influenced the leaf greenness, ranging from pale green at $65 \mathrm{ppm} \mathrm{N}$ to dark green at $260 \mathrm{ppm} \mathrm{N}$. At $520 \mathrm{ppm}$, plants showed symptoms of nitrogen toxicity, the leaf had brown and yellow patches. Increasing $\mathrm{N}$ fertilization increases chlorophyll accumulation and greenness of leaves [17, 18]. However, excessive $\mathrm{N}$ can cause the burning of leaves and changes in the uptake of other important nutrients. Interestingly, the insect infestation levels varied according to the leaf greenness; fewer and no insects were found on plants exposed to the highest $\mathrm{N}$ treatment (which had yellow leaf patches) and the lowest $\mathrm{N}$ treatment (pale green leaves), respectively, compared to the treatment $(260 \mathrm{ppm} \mathrm{N})$ that had plants with dark green leaves. This finding is in contrast to that of Schaefer and Rolshausen (2007) [19], who found a strong positive correlation between aphid numbers and fruit production and concluded that leaf color as the visual signal might not be the important determinant in aphid infestation [19].

Many studies have shown that nitrogen application alters plant primary and secondary metabolites contents and consequently plant resistance against insectivorous insects [10, 20, 21]. For example, a high level of nitrogen causes tomato plants to release less volatiles and increase the attraction of more Bemisia tabaci [21]. Aphid size, fecundity, and density positively correlated with $\mathrm{N}$ fertilization [22]. Changes to primary metabolism, including increased synthesis of carbohydrates, may make more nutrients available to insects. Also, reducing secondary metabolites, including anti-oxidant, may make plants to be more vulnerable to herbivory. Future studies should look at metabolomics and probe the relationship nitrogen-plant-metabolites-herbivory for a more comprehensive understanding of plant physiological responses to variations in $\mathrm{N}$ level.

This current study also revealed that flowering in sweet chili was significantly higher in plants exposed to the lowest $\mathrm{N}$ concentration. These results are in agreement with the findings of Khaosumain et al 2013 [23], which showed that the higher N rates (320 and $640 \mathrm{~g} \mathrm{~N} /$ tree) resulted in a reduced flowering percentage in Logan trees [23].

\section{CONCLUSION}

In conclusion, hydroponic growers may benefit from fertilizing $C$. апnиит (cultivar, California wonder) with $65 \mathrm{ppm}$ $\mathrm{N}$ because this $\mathrm{N}$ dose increases flowering and reduce insect herbivory. The study also revealed that greenness could influence insect herbivory on this chili.

\section{ACKNOWLEDGEMENT}

This work was supported by the Cape Peninsula University of Technology, South Africa through the University Research Fund (URF), grant number R166.

\section{REFERENCES}

[1] V.V. Shah, N.D. Shah, and P.V. Patrekar, "Medicinal plants from Solanaceae Family," Research Journal of Pharmacy and Technology, vol. 6, pp. 143-151, 2013.

[2] B.K. Saleh, A. Omer, and B. Teweldemedhin, "Medicinal uses and health benefits of chili pepper (Capsicum spp.): A review," Food Processing Technology, vol. 6, no. 4, pp. 325-328, 2018.

https://doi.org/10.15406/mojfpt.2018.06.00183

[3] L.R. Howard, S.T. Talcott, C.H. Brenes, and B. Villalon, "Changes in phytochemical and antioxidant activity of selected pepper cultivars (Capsicum sp.) as influenced by maturity," Journal of Agriculture and Food Chemistry, vol. 48, pp. 1713-1720, 2000. https://doi.org/10.1021/jf990916t

[4] F. Nchu, Y. Matanzima, and C.P. Laubscher, "Prospects of N fertilization in medicinal plant cultivation," Intech Open, pp. 209-222, 2018.

https://doi.org/10.5772/intechopen.68165

[5] M. Razaq, P. Zhang, and H.S. Salahuddin, "Influence of nitrogen and phosphorous on the growth and root morphology of Acer mono," PLOS One, 2017. p. 1-13. https://doi.org/10.1371/journal.pone.0171321

[6] Y. Hua, O. Goçer, and K. Goçer, "Spatial mapping of occupant satisfaction and $€$ indoor environment quality in a LEED platinum campus building," Building and Environment, vol.79, pp. 124e137, 2014.

https://doi.org/10.1016/j.buildenv.2014.04.029.

[7] AD. Halverson, and M. Bartolo, "Chile pepper response to nitrogen fertilization," Agricultural Research Service, pp. 34-42, 2010.

[8] K. Abid, S.N.M. Shah, A. Rab, M. Sajid, K. Ali, A. Ahmed, and S. Faisal. "Influence of nitrogen and potassium levels on growth and yield of chillies (Capsicum annuum L.)," International Journal of Farming and Allied Sciences, vol. 3, no. 3, pp. 260-264.

[9] S.L. Tisdale, W.L. Nelson, D. James, and L. John, "Soil fertility and fertilizers," 5th Ed. Macmillan Publishing Co, Inc. New York, 684, 1995.

[10] L. Kong, Y. Xie, L. Hu, J. Si, and Z. Wang, "Excessive nitrogen application dampens antioxidant capacity and grain filling in wheat as revealed by metabolic and physiological analyses," Scientific Reports, vol. 7, pp. 43363, 2017

https://doi.org/10.1038/srep43363

[11] SARE (Sustainable Agricultural Research and Education. 2012. Impacts of Fertilizers on Insect Pests. https://www.sare.org/Learning-Center/Books/Manage-Insects-on-YourFarm/Text-Version/Managing-Soils-to-Minimize-Crop-Pests/Impacts-of -Fertilizers-on-Insect-Pests

[12] S. Biswas, B. Mahato, P. Panda, and S. Guha, "Effect of different does of nitrogen on insect pest attack and yield potentiality of okra, Abelmonschus esculentus (L.) Moench at terai ecology of west Bengal," Journal of Entomological Research, vol. 33, no. 3, pp. 219-222, 2013.

[13] K.A.A. Draz, A.A.E. Darwish, and R.M.M. Tabikha, "Effect of different rates of nitrogen fertilizer on infestation level with piercing sucking insect pests of tomato crop, Lycopersicon esculentum," Journal of Agriculture and Environment Sciences, vol. 12, no. 3, pp. 20-31, 2013.

[14] P. Kumar, and S. Saini, "Nutrients for hydroponic systems in fruit crops. In: Urban Horticulture - Necessity of the Future,” IntechOpen, 2020. https://doi.org/10.5772/intechopen.90991

[15] J.B. Chen, C.C. Dong, X.D. Yao, and W. Wang, "Effects of nitrogen addition on plant biomass and tissue elemental content in different degradation stages of temperate steppe in northern China," Journal of Plant Ecology, vol. 11, no. 5, pp. 730-739, 2018. https://doi.org/10.1093/jpe/rtx035

[16] R.L. Walker, I.G. Burns, and J. Moorby, "Responses of plant growth rate to nitrogen supply: a comparison of relative addition and $\mathrm{N}$ interruption treatments," Journal of Experimental Botany, vol. 52, no. 355, pp. 309-317, 2001.

https://doi.org/10.1093/jexbot/52.355.309 
[17] B. Bojović, and A. Marković, "Correlation between nitrogen and chlorophyll content in wheat (Triticum aestivum L.)," Kragujevac Journal of Sciences, pp. 69-74, 2009.

[18] M. Takebe, and T. Yoneyama, "Measurement of leaf color scores and its implication to nitrogen nutrition of rice," Plants, pp. 86-93, 1989.

[19] H.M. Schaefer, and G. Rolshausen, "Aphids do not attend to leaf colour as visual signal, but to the handicap of reproductive investment," Biology letters, vol. 3, no. 1, pp. 1-4, 2007 https://doi.org/10.1098/rsbl.2006.0548

[20] M.H. Ibrahim, H.Z. Jaafar, A. Rahmat, and Z.A. Rahman, "Effects of nitrogen fertilization on synthesis of primary and secondary metabolites in three varieties of Kacip Fatimah (Labisia pumila Blume)," International journal of molecular sciences, vol. 12, no. 8, pp. 5238-5254, 2011. https://doi.org/10.3390/ijms 12085238

[21] M.N. Islam, A.T.M. Hasanuzzaman, Z.F. Zhang, Y. Zhang, and T.X. Liu, "High level of nitrogen makes tomato plants releasing less volatiles and attracting more Bemisia tabaci (Hemiptera: Aleyrodidae)," Frontiers in Plant Sciences vol. 8, pp. 1-13, 2017. https://doi.org/10.3389/fpls.2017.00466

[22] E. Nevo, and M. Coll, "Effect of nitrogen fertilization on Aphis gossypii (Homoptera: Aphididae): Variation in size, color, and reproduction," Journal of Economic Entomology, 2001. 94(1): p. 27-32. https://doi.org/10.1603/0022-0493-94.1.27

[23] Khaosumain, Y., C. Sritontip, and S. Changjeraja, Effects of different nitrogen fertilization doses on growth, leaf nutrient concentration, flowering and fruit quality in off-season longan ishs," Acta horticulturae, vol. 984, pp. 271-274, 2013.

https://doi.org/10.17660/ActaHortic.2013.984.31

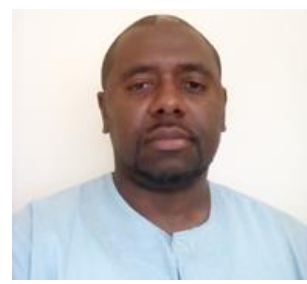

Felix Nchu was born and raised in Cameroon, obtaining a Bachelor's of Sciences in Botany from the University of Dschang in Cameroon. Felix Nchu moved to South Africa, where he received a Master's in Biology from the University of Limpopo and a PhD in Veterinary Sciences from the University of Pretoria (UP), South Africa. He was a doctoral and postdoctoral fellow at the International Centre of Insect Physiology and Ecology (ICIPE) in Nairobi and the FitzPatrick Institute of African Ornithology, University of Cape Town (UCT), respectively.

Currently, he is an Associate Professor in the Department of Horticultural Sciences, Cape Peninsula University of Technology (CPUT). He supervises many postgraduate students and serves as a Chairperson of the Faculty Research Ethics Committee of the Faculty of Applied Sciences, CPUT. He is a co-founder and coordinator of the African Consortium of Ticks and Tick-borne Diseases (AfriCoTT) - the consortium coordinates research and surveillance of ticks and tick-borne diseases in Africa. Broadly, his research focuses on developing biorational approaches for control of arthropod pests. Specifically, he researches the ecology, physiology, and bioactivities of plants and arthropod-pathogenic fungi. He has published extensively in reputable journals.

Prof Felix Nchu serves as a reviewer and an editorial board member for several scientific journals. In 2013, Prof Nchu received the first prize for the most innovative community engagement and service learning project in the Cape Peninsula University of Technology. Prof Nchu is an active member of the Acarological Society of America (ASA), Parasitological Society of Southern Africa (PARSA) and the International organisation for Biological Control (IOBC).

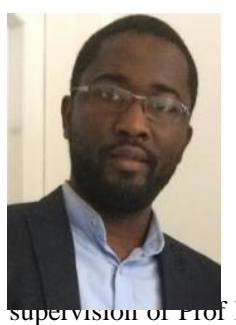

Ninon G.E.R. Etsassala was born in the Republic of Congo. He obtained a Bachelor's of Sciences in Chemistry from the University of Marien Ngouabi, Republic of Congo in 2010. He moved to South Africa, where he graduated with a BSc Honours in March 2014, a Master of Science in August 2016 and PhD in March 2020 at the University of the Western Cape. Currently, Ninon G.E.R. Etsassala is a Postdoctoral Fellow at Cape Peninsula University of Technology under the Felix Nchu. He has published many research articles and scientific reviews in reputable international journals with specialization in
Organic chemistry, electrochemistry, biochemistry and horticulture. He is also an active registered member of the South African Chemical Institute (SACI). 